\title{
SETTLEMENT BEHAVIOUR OF STABILISED PEAT: AN ASSESSMENT WITH ECO-PROCESSED POZZOLAN (EPP) IN MODIFIED ELECTRO-OSMOTIC TRIAXIAL CELL
}

\author{
Anis Anisha Suhaimi ${ }^{1}$ and ${ }^{*}$ Habib Musa Mohamad ${ }^{2}$ \\ ${ }^{1,2}$ Faculty of Engineering, Universiti Malaysia Sabah, Kota Kinabalu, Sabah, Malaysia \\ *Corresponding Author, Received: 19 Aug. 2021, Revised: 31 Oct. 2021, Accepted: 01 Dec. 2021
}

\begin{abstract}
Peat's settlement behavior is a classic problem in construction. The dominant feature of peat is when subjected to load, it is noted for its great compressibility, high moisture content, poor shear strength, and long-term settlement. This study adopts the method of electro-osmotic to stabilize peat soil with Eco Processed Pozzolan (EPP) in the modified electro-osmotic triaxial cell. Peat samples were tested incorporated of the controlled; peat soil, and treated samples; peat soil with $70 \%$ of EPP, peat soil with $50 \%$ of EPP and $50 \%$ of cement, and peat soil with $70 \%$ of EPP and $30 \%$ of cement. EPP and cement were mixed with $10 \mathrm{ml}$ of EPP's liquid concentration. The objective of this study is to investigate the characteristics of peat soil settlement behavior on the load-carrying capacity and its compressibility and to assess the chemical properties of peat soil stabilized with EPP, and addition of binder, cement before and after the treatment. In this study, the results show that EPP coupled with cement is qualified to reduce the settlement behavior of peat soil with the addition of a stabilizer. It is observed that the settlement behavior of peat soil mixed with $70 \%$ of EPP and $30 \%$ of cement underwent small-scale settlement at first and remained constant. Peat soil coupled with $50 \%$ of EPP and cement has shown a significant improvement compared to the control sample and peat soil with $70 \%$ of EPP. Additionally, the mixes were examined using Scanning Electron Microscopy (SEM) and X-ray powder diffraction (XRD) for phase identification of a crystalline material between peat and EPP relationships. The analyzed material composition shows crystallization process occurs between peat and EPP filled the void that presents in peat soils and reduced the voids. It was found that peat soil mixed with EPP and cement has a smoother surface texture and is less porous and voids, In contrast to the controlled sample, there are more voids present in the surface imaging.
\end{abstract}

Keywords: Eco-processed pozzolan (EPP), Settlement behavior, Peat soil, Stabilization

\section{INTRODUCTION}

In the literature, peat soil is defined as the organic surface layer of a soil consisting of moderately decomposed organic matter, primarily derived from plant material that has formed under conditions of waterlogging, depletion of oxygen, high acidity and depletion of nutrients.

Peat soil is encountered in many areas and generally originates from plant or animal remains and is considered partly as decomposed biomass as claimed [1]. Pursuant [2], the disintegration of plant in acidic environments without microbial activity generates highly organic matters in peat soil. Moisture and temperature affected the peat formation. The decomposition of plant material by microorganisms is decelerated in cold temperatures, leading to rapid peat formation. In lowland and highland areas, peat soils can exist, but highland peat soils are not widespread. Peat soil is considered as one of the problematic soils. The bearing capacity of peat soil is very low and apparently controlled by the water table and presence of subsurface woody debris [3].
Reduction in the level of groundwater may eventually lead in the deterioration and oxidation of the peat, given the increase in compressibility and permeability likely to result in its humification. According to [4], it is commonly reported that tropical peat soils associated with highest settlement when subjected to a load over long period. Excessive settlement happens when buildings are built on peat soil and thus creates problems of instability.

This can be exemplified in problems as local sinking and long-term settlement [22], even if it is applied to moderate pressure. For example, when provided present existence, many constructions project and coastal high-rise buildings whose bases are often backed by peat soils face complications. As far as peat soil is concerned, one of several methods or techniques used to increase the determination and strength of soft soil is electroosmotic consolidation procedure for ground improvement on soft soil.

Previous researchers have reported the applications of electro-osmosis to numerous projects. Electro-Osmosis usage in pile capacity 
improvement and was reported [5]. [16] Outlined the application of Electro-Osmosis in foundation reinforcement and [6] in embankment stabilization. For this reason, electro-osmosis exhibits impressive excellence among these applications in reinforcing high efficiency fine-grained soils, such as silts, where traditional approaches, such as pre-loading or vacuum loading, have less favorable effects, particularly in terms of time demand. Thus, this study modified triaxial cell as electro-osmotic chamber because the principles used are the same according to what has been designed by [16].

In terms of Eco Process Pozzolan or known as EPP, it is a sustainable product recycled from spent bleaching earth (SBE), and recently used as a blended cement as specified by [7]. EPP primarily consists of silica $\left(\mathrm{SiO}_{2}\right)$, aluminum oxide $\left(\mathrm{Al}_{2} \mathrm{O}_{3}\right)$, and iron oxide $\left(\mathrm{Fe}_{2} \mathrm{O}_{3}\right)$. In agreement with [7], the combination of the three substances is more $50 \%$, which can be classified as class $C$ pozzolan based on ASTM C618 standard.

EPP has been used as blended cement recently. Research on EPP as a pozzolanic material from previous studies is minimal. Waste products with pozzolanic properties are used for cement replacement in concrete, thus reducing the use of cement. The use of pozzolanic material for cement replacement could reduce the cement industry's release of carbon dioxide $(\mathrm{CO})$ because cement production contributes to $5 \%-7 \%$ of global $\mathrm{CO}$ emissions in keeping with [13]. The original EPP was visually found to be mostly coarser and porous in nature. The mineralogical analysis indicates that the EPP consists of various minerals, either in the crystalline phase or in the amorphous phase, as it has $\mathrm{SiO} 2$. The pozzolanic reactivity of the material can be more dependent than other properties of the material on the occurrence of its amorphous level.

Tropical peat soils undergo large settlements in comparison to clays when subjected to loading [8]. Electro-osmotic consolidation has been shown to be an effective method of improving soft soil and improving shear strength and slope and embankment stability, especially for very low hydraulic conductivity soils. The compressibility of soil generally consists of three stages namely initial compression, primary consolidation, and secondary compression. Initial compression occurs instantaneously after the load is applied; whereas primary and secondary compressions depend upon the length of time the load is applied. The secondary compression would begin after the surplus pore water pressure had been dissipated at constant vertical stress. Peat's compression behavior differs from that of other types of soils in two respects. For starters, peat has a far higher compression than other soils. Second, in peat, the creep portion of settlement is more important than in other soil types in determining overall settlement.
Fiber content, natural water content, void ratio, initial permeability, structure and arrangement of soil particles, and inter-particle chemical interaction in some soils are the most important elements regulating peat compressibility [9]. Although the rate of primary consolidation of fibrous peat is quite fast, it slows down when consolidation pressure is applied. The considerable reduction is related to a decrease in permeability as a result of increased pressure. The properties of peat reflect the environment of peat formation, peat creation processes and the types of peat-forming plants. The physical properties of peat include the rate of decomposition, the content of water, specific density, density of bulk, etc. Typically, according to the degree of decomposition, peat can be graded into low decomposition, moderate decomposition and high decomposition [10].

The degree of peat decomposition, as well as other peat properties, is closely related to the depositional condition of the peat and the types of peat-forming plants. Elemental composition, organic elements, and ash involve the chemical properties of peat. $\mathrm{C}, \mathrm{H}, \mathrm{O}, \mathrm{N}$ and $\mathrm{S}$ are the five essential elements of peat. The classification of Von Post is commonly used by most researchers to assess the degree of on-site humification, [11]. The von Post humification test (von Post classification system) involves squeezing between the fingers the peat and the material that is exuded, inspecting the material, and classifying the soil as belonging to one of ten groups of humification or decomposition (H1-H10). The low bulk density and high-water table in peat soil cause only a discernible increase in strength with depth [12].

\section{RESEARCH SIGNIFICANCE}

This study's findings will redound to technology's benefit, considering that EPP plays a vital role in peat soil stabilization material and technology. The findings of this research are to enlighten and dig deeper into the usage of EPP material coupled with cement as a binder in soil stabilization for peat soil in order to get the better out of the problematic soils. This research was done to fill the gap on settlement behaviour of peat soil using stabilizer and binder with certain concentration. This technique helps the engineers to fathom the problems for peat soil and in the same way establish a new method in the industry.

\section{MATERIALS AND TESTING}

This research is designed to determine the effect of Electro-Osmotic Consolidation Technique on Cement-binder and EPP-stabilized peat soil. This research conducted in accordance with BS1377: 1990, British Standard Research Methods for Soil 
Civil Engineering Purposes. This study explains in particular aspect the methods used and outlines an experimental assessment suggested in this study of peat soil compressibility action. To perform the specified sequential soil extraction samples, samples from Klias, Beaufort Sabah (KBpt) were collected. Samples were transferred from the field to the Geotechnical Laboratory of Universiti Malaysia Sabah. Four test breakdowns, index properties, settlement behaviour testing, chemical analysis, X-ray powder diffraction (XRD) and imaging analytics are conducted in this study.

For the settlement behaviour testing, modified triaxial cell for electroosmotic chamber used with applied loading at $2.1 \mathrm{kPa}$, for a time period of 2 hours. The treated soil with different concentration of EPP and cement mixed with $10 \mathrm{ml}$ of liquid concentration undergone the same loading behaviour testing as untreated samples.

As for imaging analytics, scanning electron microscopes (SEM) were done for both treated and untreated samples. EPP diluted in $10 \mathrm{ml}$ distilled water and then penetrated into peat soil specimen in electro-osmotic chamber by implementing injection method. Sample was injected with EPP concentration at different layers in $30 \mathrm{~mm}, 60 \mathrm{~mm}$, $90 \mathrm{~mm}$ and $120 \mathrm{~mm}$ height. Settlement experiments are carried out on a saturated cylindrical soil sample with diameter $90 \mathrm{~mm}$ and height is $150 \mathrm{~mm}$ and are designed to determine the volume and rate at which, when subjected to load, a sample can shift in height. The sample is radially confined such that the vertical height will change when a vertical load (stress) is applied to the sample. Settlement test are done on both samples, treated sample, which are stabilized by EPP and untreated sample, which is only peat soil. This cell is modified from triaxial cell for electro-osmotic cell treatment technique without electro-osmotic process for settlement test and shown in Figure 1.

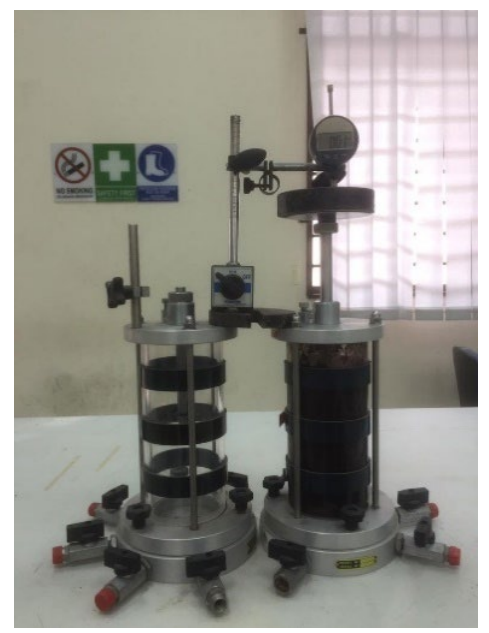

Fig.1 Settlement versus time curves

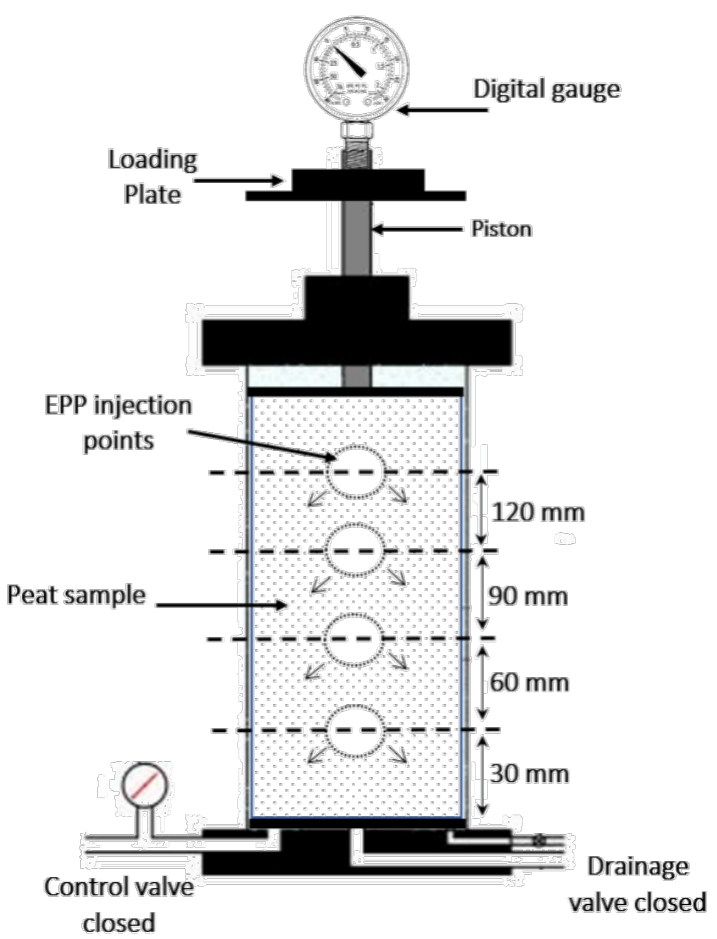

Fig.2 Schematic diagram for loading phase

Figure 2 shows the schematic diagram of loading phase for peat soil sample that was loaded to 120 minutes to determine the pre-settlement behaviour of peat soil in modified triaxial cell. No drainage allowed and pressure valve closed. Load in vertical position perpendicular loaded the sample and measured by using digital gauge.

\subsection{Index Properties Test}

\subsubsection{Moisture Content Test}

The natural moisture content of peat soil was found to be 580.5 percent in this investigation. Peat moisture content can range from 200 to 2000 percent, according [9], which is considerably different from clay and silt deposits, which rarely reach 200 percent.

The moisture content for KBpt is accepted to be between the ranges, according to the prior result. In previous studies on moisture content, different number of moisture content have been found, ranges from 491.16 to 985.3 percent according to [14], 678 percent according to [15], and 546.43 percent according to [16]. The moisture content of the soil and its shear strength are inversely proportional on the authority [17].

According to [18], these differences in results are due to climate change as a consequence of changes in temperature, precipitation, and rainfall influencing soil saturation intensity, in which the water table forms in a comparably horizontal plane and may emergence to a level greater or less than the actual water table [22]. 


\subsection{2 pH Test}

The $\mathrm{pH}$ value for peat, EPP and peat with EPP in this investigation was found to be 3.21 on the acidic scale, 13.02 on alkaline scale and 9 on alkaline scale respectively [14] found that the acidity of peat is ranging between 4.0 to 4.9 , [17] found that the $\mathrm{pH}$ of peat is between 3.16 to 3.71 , and [16] also found that $\mathrm{pH}$ of peat ranging from 3.3 to 3.9 on acidic scale. According to [14], the acidity of tropical peat soils ranges from 3 to 5 [23].

Table 1 Index properties of Beaufort peat soil

\begin{tabular}{cc}
\hline Descriptions & Rate \\
\hline Moisture content & $580.5 \%$ \\
pH of peat & 3.21 \\
pH of ground water & 3.40 \\
Peat physical colour & Dark brown \\
Linear shrinkage & $4.29 \%$ \\
Degree of humification & $\mathrm{H} 4$ \\
\hline
\end{tabular}

Consequently, this finding is regarded as adequate because it is within the range of previous researchers' findings, as shown in Table 1 shows the index properties of KBpt. Poor hydrolysis of organic acids resulting from the decomposition of organic compounds causes surly nature on peat soil. Organic acids, according to [20], play a key role in low $\mathrm{pH}$ soils. Variability in soil $\mathrm{pH}$ is determined by the rate of organic material decomposition (decay) and the depth of peat Table 2 shows the significant results from $\mathrm{pH}$ test. Peat determined as acidic (3.21) and EPP as alkaline with rate is 13.02. Significantly, there is a slightly significant change in peat condition from highly acidic to alkaline when mixed with EPP. These significant changes closely related to the crystallization process and EPP as filler material and described in XRD test results. It is observed that, the EPP amount that presents in peat soil tend to modified the acidic behaviour of peat soil. This phenomenon is believed related to the mineralization process. The formation of new elements helps the peat stabilization process by using EPP and cement significantly. EPP shows a adequate reaction in the stabilization process with the presence of sufficient water in the peat which helps the movement of the EPP component as a filler.

Table $2 \mathrm{pH}$ value of KBpt and EPP

\begin{tabular}{ccc}
\hline Sample & $\mathrm{pH}$ Value & Description \\
\hline Peat & 3.21 & Acidic \\
EPP & 13.02 & Alkaline \\
Peat $+70 \%$ of EPP & 9 & Alkaline \\
\hline
\end{tabular}

\subsubsection{Test Design and Liquid Concentration}

Settlement behaviour test was conducted on KBpt samples. In the course of settlement behaviour test, the sample was left undisturbed and moulded in an electro-osmotic triaxial cell. Throughout the experiment, data such as settlement (mm) and time taken for settlement to occur ( $\mathrm{min}$ ) was recorded as parameters of finding. There are 4 samples being tested. Each samples have a height of $150 \mathrm{~mm}$, a diameter of $90 \mathrm{~mm}$, and was subjected to a pressure of $2.1 \mathrm{kPa}$ for 120 minutes or 2 hours.

As was pointed out above, the 4 samples that were tested can be categorised into Mix 1, Mix 2, Mix 3 and Mix 4. Mix 1 is the controlled sample, peat soil without any addition of stabilizer being EPP or cement functioning as a binder. Mix 2 is peat soil with the addition of EPP by $70 \%$ in concentration. Mix 3 differs from Mix 4 in the matter of concentration of stabilizer and binder combined. Mix 3 is peat soil coupled with equal concentration of EPP and cement, that are 50\% respectively, whereas Mix 4 is peat soil combined with $70 \%$ of EPP and $30 \%$ of cement.

Both EPP and cement come in powder form. Subsequently, EPP and cement were weighed to a specific weight of $5 \mathrm{~g}, 7 \mathrm{~g}$, and $3 \mathrm{~g}$ correspondingly, and then mixed in $10 \mathrm{ml}$ of distilled water. For Mix 2, EPP is added into $10 \mathrm{ml}$ of distilled water, afterwards injected into the mold. For Mix 3 and Mix 4, EPP and cement of specific weight are added into $10 \mathrm{ml}$ of distilled water and injected into the mould. Sample are then allowed to harden for 24 hours before subjugated to pressure. Table 3 shows the testing design and mixes proportion for each specimen. There are 4 designs was prepared and Mix 1 as a control, Mix 2 for peat and EPP (70\%) content in concentration. Mix 3 and 4 designed for EPP mixed with cement in different cement content.

First, the checking of the index properties to determine the characteristics of the peat sample, driven by references to various parameters for the purposes of classification and identification. Next, the settlement test by using modified electroosmotic triaxial cell test. This helps work for the compressibility of peat. Despite this, when preparing good samples, peat has a uniform structure and challenges. Peat has a high specificity when having a good sample prepared, and it is important to track the test process, but taking it one step further also results in unpredictable testing. All the samples that put through the settlement behaviour test were then tested for imaging analytics to further analysed the surface texture of every mix and each sample. Scanning Electron Microscopy (SEM) was done to all the samples including peat, cement, EPP, peat and $70 \%$ of EPP, peat with $70 \%$ of EPP and $30 \%$ of cement, and peat with $50 \%$ of both EPP and cement. 
Table 3 Mixed design and EPP with cement in liquid concentration

\begin{tabular}{|c|c|c|c|c|}
\hline Samples & Mix 1 & Mix 2 & Mix 3 & Mix 4 \\
\hline Description & Peat Soil & $\begin{array}{c}\text { Peat Soil with } 70 \% \text { of } \\
\text { EPP }\end{array}$ & $\begin{array}{c}\text { Peat Soil with } 50 \% \text { of } \\
\text { cement and } 50 \% \text { of } \\
\text { EPP }\end{array}$ & $\begin{array}{c}\text { Peat Soil with } 30 \% \\
\text { of cement and } 70 \% \\
\text { of EPP }\end{array}$ \\
\hline $\begin{array}{l}\text { Time to Harden (h) } \\
\text { Mixture }\end{array}$ & - & $\begin{array}{c}- \\
7 \mathrm{~g} \text { of EPP } \\
10 \mathrm{ml} \text { of distilled } \\
\text { water }\end{array}$ & $\begin{array}{c}24 \text { hours } \\
5 \mathrm{~g} \text { of cement } \\
5 \mathrm{~g} \text { of EPP } \\
10 \mathrm{ml} \text { of distilled water }\end{array}$ & $\begin{array}{c}24 \text { hours } \\
3 \mathrm{~g} \text { of cement } \\
7 \mathrm{~g} \text { of EPP } \\
\text { 10ml of distilled } \\
\text { water }\end{array}$ \\
\hline $\begin{array}{l}\text { Depth of Injection } \\
(\mathrm{mm})\end{array}$ & 3.1 & $\begin{array}{l}50 \mathrm{~mm} \\
100 \mathrm{~mm} \\
150 \mathrm{~mm} \\
3.1\end{array}$ & $\begin{array}{c}50 \mathrm{~mm} \\
100 \mathrm{~mm} \\
150 \mathrm{~mm} \\
3.1\end{array}$ & $\begin{array}{c}50 \mathrm{~mm} \\
100 \mathrm{~mm} \\
50 \mathrm{~mm} \\
3.1\end{array}$ \\
\hline
\end{tabular}

\section{RESULT AND DISCUSSION}

Figure 3 shows the settlement behaviour of untreated peat soil and treated with EPP and Cement. Fortunately, for the untreated peat soil, the settlement behaviour is seen to be high at $-1.92 \mathrm{~mm}$ after 2 hours that imposed with $3.1 \mathrm{kPa}$ loading. Unfortunately, for treated sample contains with $70 \%$ EPP (Mix 2) is clearly seen almost constant with untreated sample which is at $-1.94 \mathrm{~mm}$ despite the settlement curve pattern is slightly deeper than Mix 1. In the event that, there is changes in settlement rate is seen at $0.01 \%$. Consequently, in the Mix 3, the behaviour significantly showing improvement. The settlement curve identically improved with EPP treatment. The development of EPP treatment generates stable settlement behaviour of peat soil at $0.81 \mathrm{~mm}$ compared to Mix 1 and Mix 2.
Therefore, the development of EPP potential as stabilizer in peat soil treatment has contributed $58.24 \%$ compared to the untreated peat soil. In addition, for the Mix 4, the settlement behaviour has been observed lesser than Mix 1, Mix 2 and Mix 3.

The generation of EPP and Cement potential as stabilizer materials for peat soil perspectivity is high. This development of Mix 4 is dormant to $99.48 \%$. Comparatively, Mix 2 is seen as lower development is stabilizing peat soil settlement. In that case, this study has observed that EPP has no effects to the peat soil without cement as binder agents. In the Mix 2, when EPP concentration injected in peat specimens, its gradually increase the moisture of peat soil and expressed in the Mix 2 settlement curve which is the curve slightly ellipse and deeper than Mix 1, Mix 3 and Mix 4.

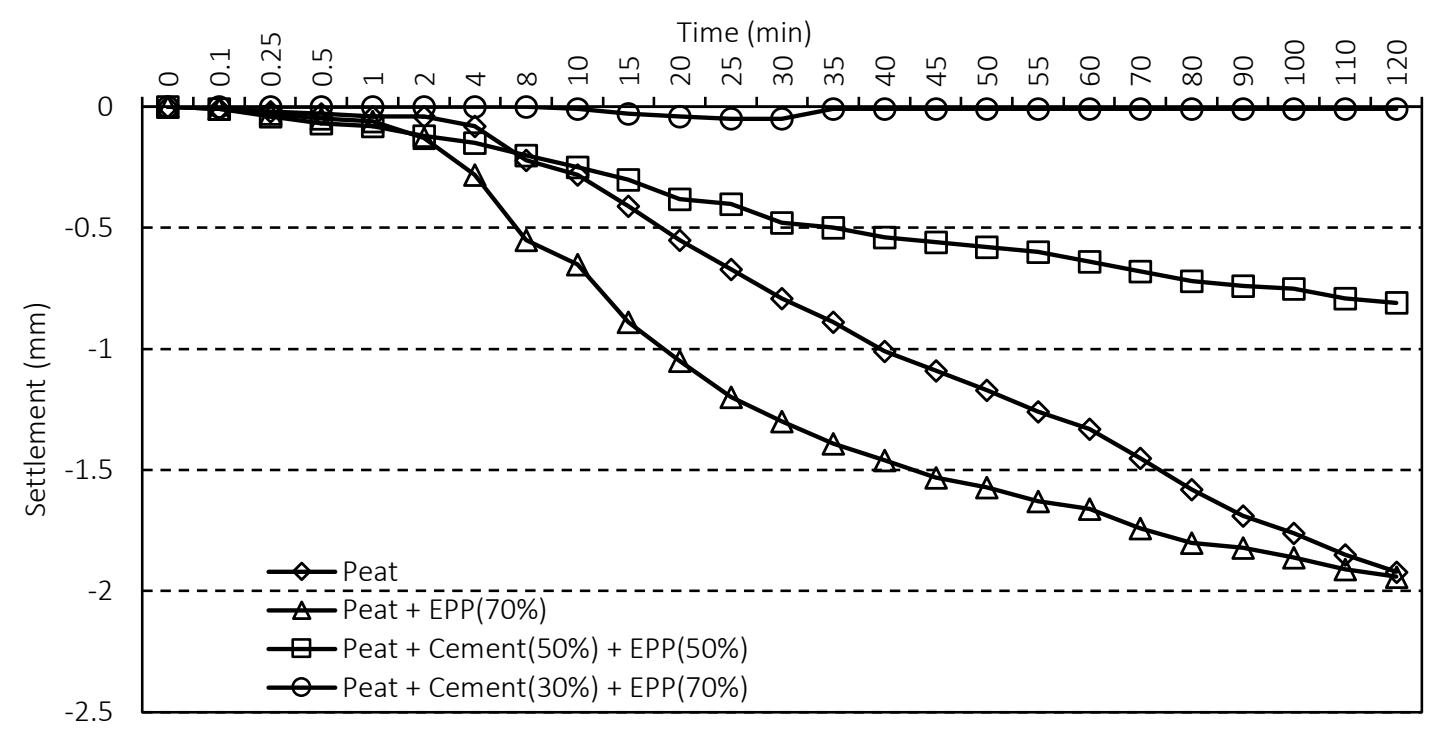

Fig. 3 Settlement versus time curves 


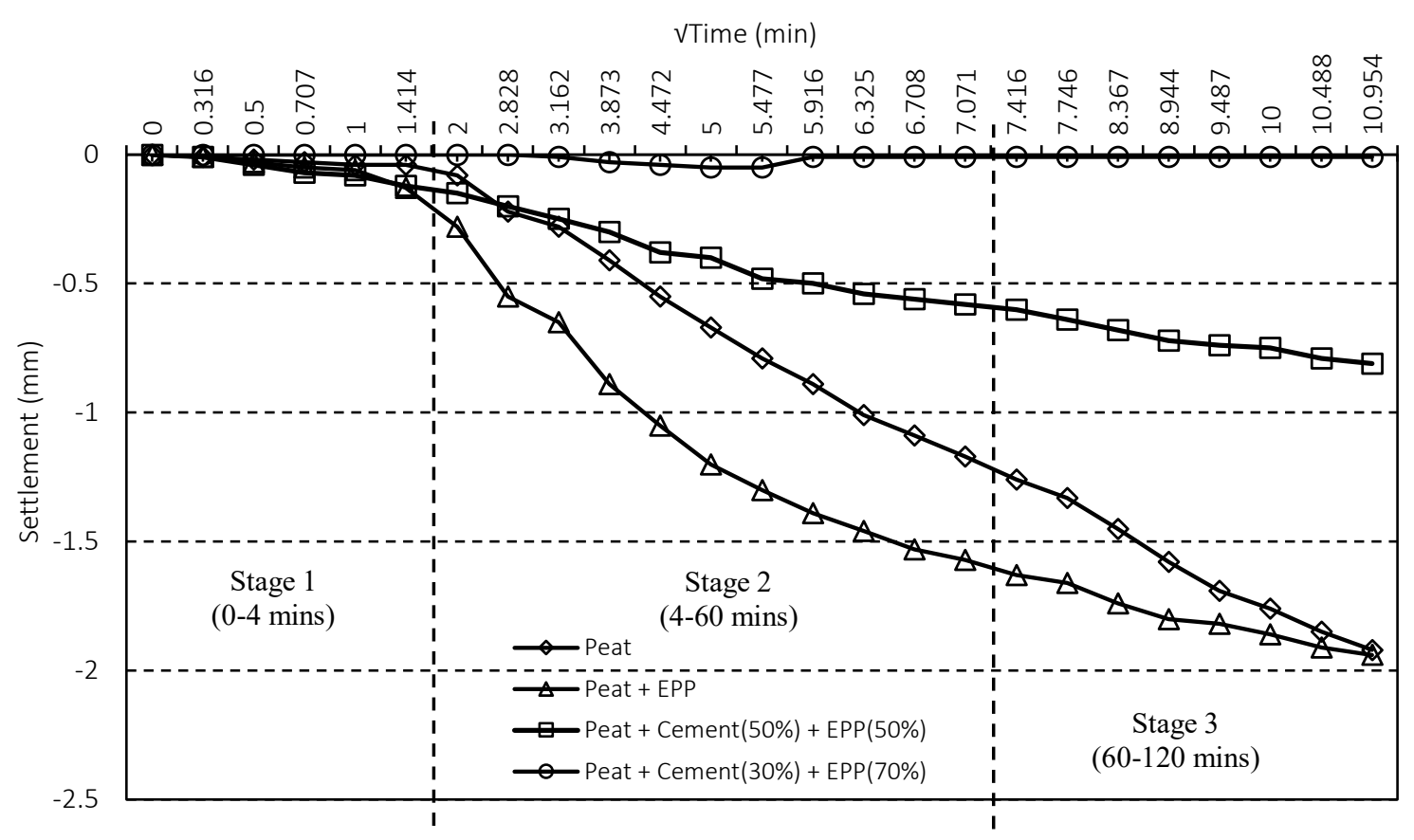

Fig.4 Settlement versus $\sqrt{t, \min }$, time

As a result, EPP coupled with Cement contributes potential in developing stable settlement in peat soil. [21] Stated that, peat soil treated with additive materials has potential to be stabilised. Figure 4 shows stages of settlement in 3 different time frames, markedly stage 1 , stage 2 and stage 3 . Stage 1 is the time frame from 0 minute to 4 minutes. In this stage, Mix 1, Mix 2 and Mix 3 had undergone settlement of $0.05 \%, 0.19 \%$ and $0.10 \%$ individually. On the contrary, Mix 4 appeared to have no settlement for the first 4 minutes. This happened because Mix 4 has already achieved stable condition or already stabilized. To put it differently, the resistance in the Mix 4 is low compared to Mix 1, Mix 2 and Mix 3.
For stage 2, it can be seen in the graph that Mix 2 continues to decline more than Mix 1 and Mix 3 . This occurred because of the addition of moisture into Mix 2, one of the major drawbacks of this is it will increase the settlement rate of the sample. Conversely, Mix 3 surpassed Mix 1 at time frame of 10 minutes and started to increase gradually contrasted to Mix 1. This implies that cement started to react to the pressure forced on the sample. At the same time, Mix 4 as well, the settlement curve started to drop a little compared to Mix 1, Mix 2 and Mix 3 by -0.03 to -0.05 throughout minutes 15 to 30 . Nonetheless, the settlement curve for Mix 4 risen again to -0.01 and remained persistent through stage 2 .

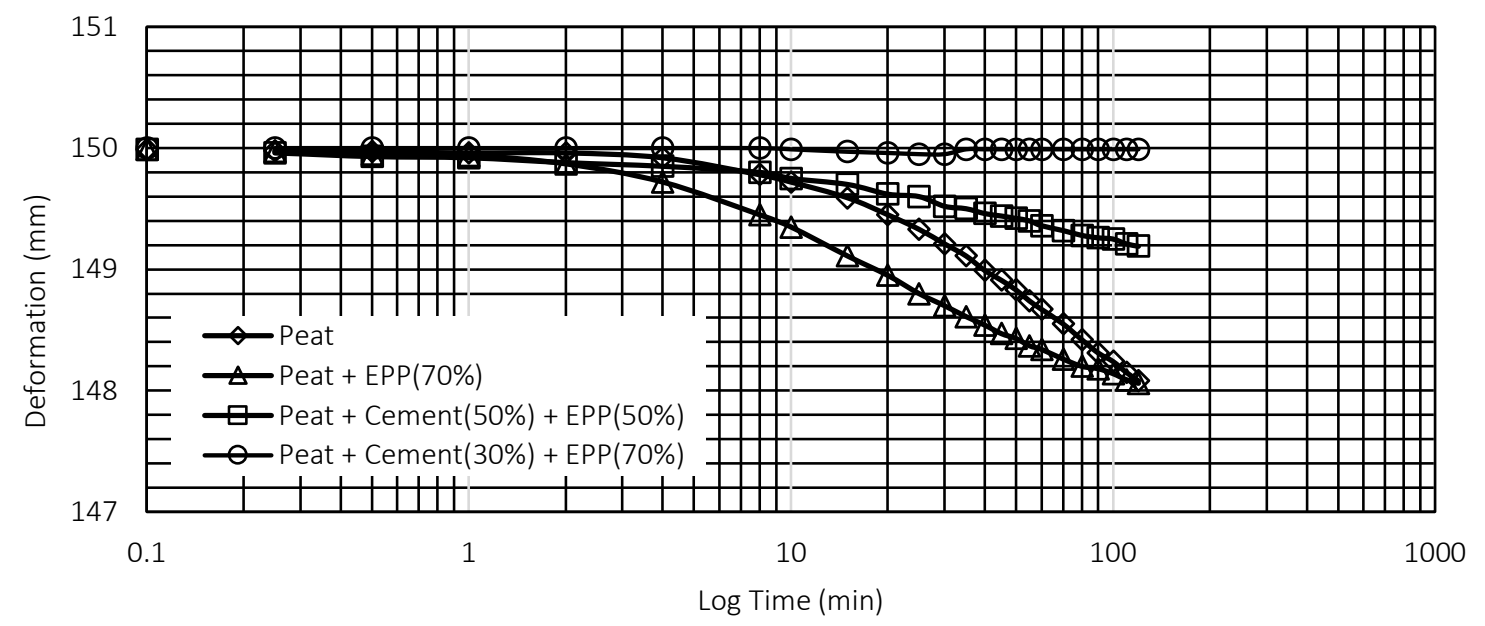

Fig.5 Deformation versus Log Time Curves 
Moving on to stage 3, the last hour of the experiment. In this stage, the author observed that Mix 1 and Mix 2 almost have the same final settlement number with differences only by $0.01 \%$. Mix 3 continues to divert far from Mix 1 and Mix 2 and stopped at settlement of $0.74 \%$ and $0.75 \%$ higher that Mix 2 and Mix 1. On the other hand, Mix 4 continues to remain constant settlement at $0.01 \mathrm{~mm}$ until 120 minutes. Mix 4 can be said to finally achieved full soil stability and will not undergone anymore settlement.

Given these points, we can say that cement act as good binder to peat soil and EPP. The amount of cement and EPP also need to be considered. Mix 3, with the same amount of EPP and cement, shows gradual increase or settlement curve almost constant indicates that the properties of soil can be improved. In the same way, for Mix 4 the amount of EPP is greater than cement and the graph shown that only little settlement occur during stage 2 , but no settlement occurred during stage 1 and the graph remain constant during stage 3 . This study has identified that EPP combined with little binder will improve the strength of peat soil or in other words, the amount of EPP must be greater than cement to improve peat soil settlement.

Figure 5 above illustrates the deformation of all samples tested against log time. As can be seen from the graph, there has been a marked drop from Mix 4 to Mix 2. All the mixes seem to have almost identical deformation for the first 1 minute before starting to drop gradually for Mix 1, Mix and Mix 3, unlike Mix 4. Given that Mix 1 is the controlled sample with no additives of stabilizer and binder.

Mix 1 deformation curve ends at $148.08 \mathrm{~mm}$ whereas for Mix 2, the curve is steeper than Mix 1. The deformation for Mix 2 at the end experiment is $148.06 \mathrm{~mm}$, with a difference of $0.01 \%$ compared to Mix 1. For Mix 3, the deformation curve deviate from deformation curve of Mix 1 and Mix 2. Mix 3 deformation curve appears to just drop slightly and ends at deformation of $149.19 \mathrm{~mm}$ with the height differences of $0.74 \%$ and $0.76 \%$ from Mix 1 and Mix 2 accordingly.

Albeit all samples had encountered deformation, Mix 4 remain constant, almost linear with only little drop at the middle of the experiment. Nevertheless, Mix 4 deformation curve stays persistent until the end. This behaviour can be explained by the chemical composition of the stabilizer and binder, namely EPP and cement. EPP is mostly made up of silica $(\mathrm{SiO} 2)$, and the mixture of $(\mathrm{SiO} 2)$, aluminum oxide (Al2O3), and iron oxide (Fe2O3) was $68.98 \%$, which is more than $50 \%$.

The reaction of $\mathrm{SiO} 2$ in pozzolonic materials coupled with calcium hydroxide invents additional $\mathrm{CSH}$ gel, henceforth has a great potential for replacing cement in pozzolanic materials. Ultimately, the CSH gel will enhance the density of the hardened paste, together with its strength and durability as stated by [7].

Figure 6 shows the void ratio at the end of a 2hour pre-settlement behaviour test for each mix. The compression by the end of 2 hours for the specified load is shown by the void ratios in this Figure 6. For Mix 1, the void ratio recorded is 103.947. For mix 2, the void ratio slightly dropped than Mix 1 which is at 103.933 , influenced by the increase in moisture. Mix 3 recorded a value of 104.734, which is $0.8 \%$ higher than Mix 2 .

Since Mix 3 is mix with EPP and cement, the mixture is denser and making the particles in the soil harder to move past one another during the application of the compacting forces. Mix 4 recorded the highest number of void ratios out of all the mixes, that is at 105.3. Similarly, as Mix 3, Mix 4 is already stable and only undergone little settlement, in other words, the mixture of $70 \%$ and $30 \%$ of EPP and cement specifically improved the settlement of the sample, making the particles even harder to slides past one another albeit the same pressure applied for 2 hours. Thus, Mix 4 documented as having the highest void ratio at 105.3 and Mix 2 possessed the lowest void ratio at 103.933 .

Figure 7 shows the scanning electron microscopes for 6 materials and mixes used in this research. Figure 7(a) manifest the surface images of cement, (b) is the images of peat soil, (c) is the images of EPP, (d) is for the treated sample or Mix 2, peat with EPP of $70 \%$ concentration, (e) is Mix 3, peat with same concentration of both EPP and cement, $50 \%$ respectively and (f) is Mix 4, peat with $70 \%$ of EPP and $30 \%$ of cement mix.

Figure 7 (b) and (d) differ in terms of void. As we can see in (b), the fibre of peat can be seen to cover the whole surface images, but there are still voids present in the sample whereas in (d), the surface images seem to possess no voids and have a smooth surface image. The SEM image shows that the EPP particles (c) was irregularly shaped, relatively spherical, and agglomerated and porous texture on its particles. When EPP is added to peat soil, crystallization process occurs.

EPP will fill the void presents in peat soil to make the peat soil less voids. This is evident as (e) and (f) also possess less voids compared to (b). For figure 7 (e) and (f), we can see that peat with EPP and cement of same concentration of $50 \%$ are a bit porous than peat with EPP of $70 \%$ and cement of $30 \%$ concentration. For (e), the peat fibre still can be seen, and as the same concentration of cement and EPP was mixed, the shape of the sample became irregular and fibrous.

In contrast to that, (f) with more concentration of EPP seems to have a smoother surface image as the higher concentration of EPP fills the void that both cement and peat possessed. 


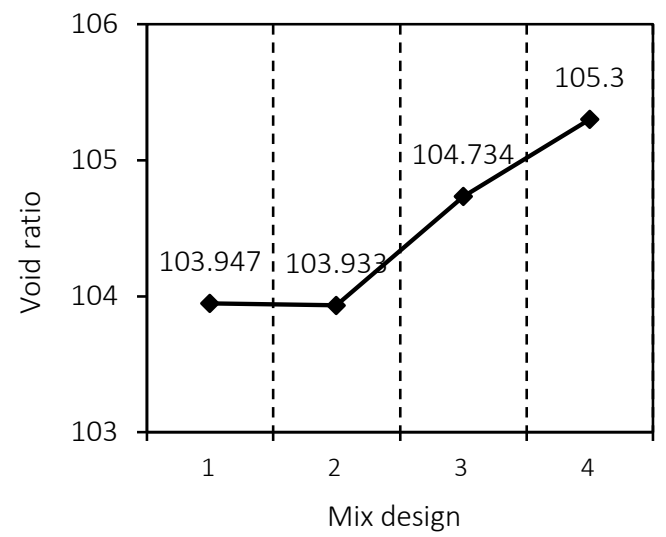

Fig.6 Void Ratio

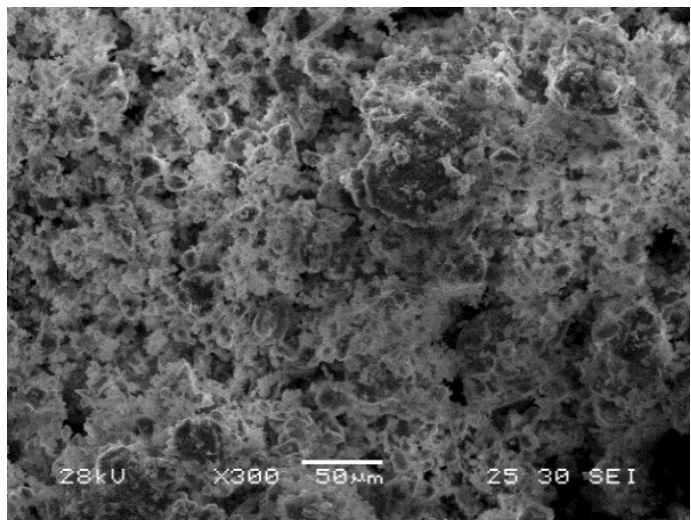

(a) Cement

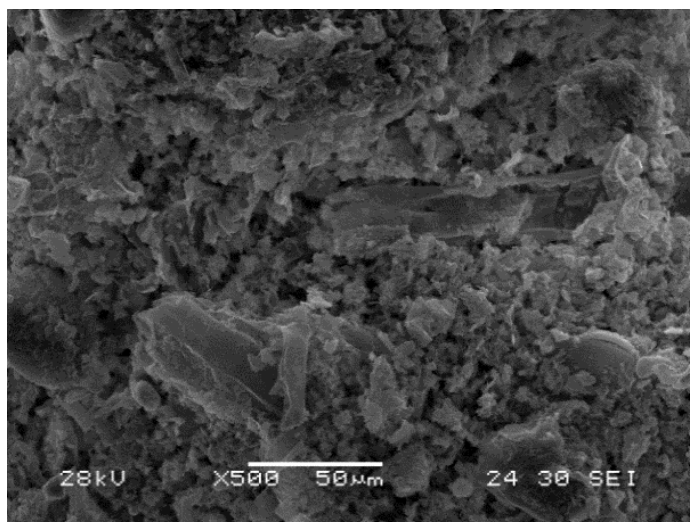

(b) Peat soil

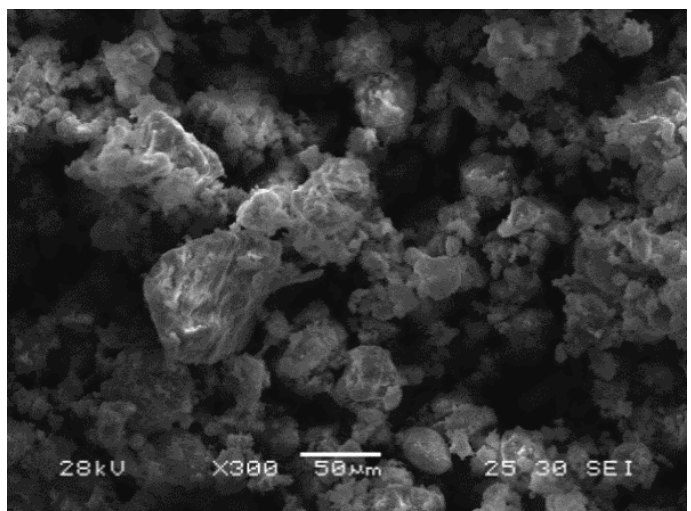

(c) Eco Processed Pozzolan (EPP)

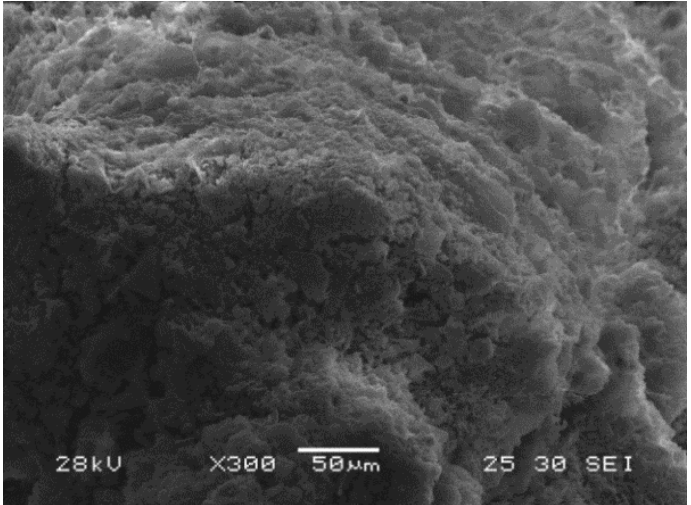

(d) Peat + EPP 70\%

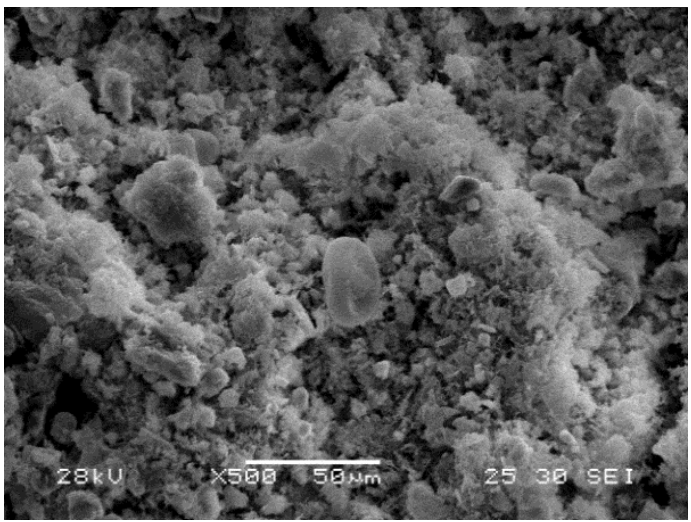

(e) Peat + EPP 50\% + Cement 50\%

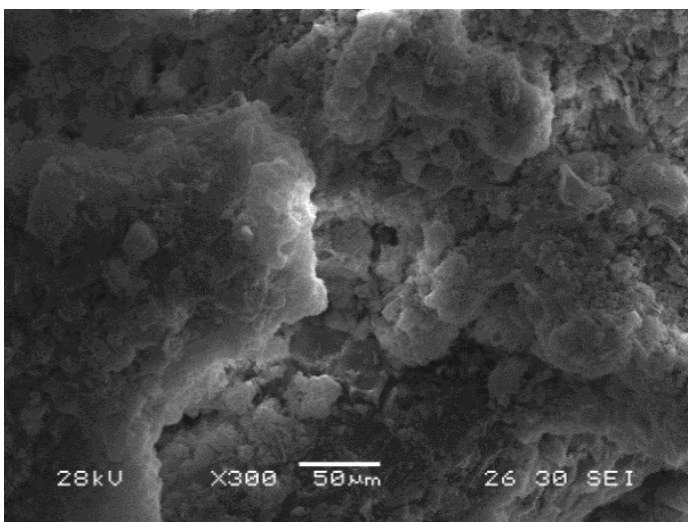

(f) Peat + EPP $70 \%+$ Cement $30 \%$

Fig.7 Scanning Electron Microscopes (SEM) images for studied materials

Figure 7 shows the Scanning Electron Microscopes (SEM) images for studied materials. Figure $7 \mathrm{~b}$ shows the high intensity of pore in black or darker area which is indicates void area in peat soil structure. Correspondingly, Figure $7 \mathrm{f}$ shows the restructuring of component in peat soil as crystallization process developed within peat, cement and EPP. To demonstrate mineralization compound in peat stabilization process, X-ray powder diffraction (XRD) performed for 
characterizing crystalline materials that formed during stabilization in peat soil using cement and EPP. Figures 8, 9 and 10 provides the information on structures, phases, crystal orientations and other structural parameters that regenerated effects from EPP to peat soil. It is observed that, broad XRD peaks of Boron Manganese (Mn B4), Montmorillonite-18A ( $\mathrm{Na} 0.3$ ( $\mathrm{Al} \mathrm{Mg}) 2 \mathrm{Si} 4 \mathrm{O} 10 \mathrm{O})$ and Quartz, syn (Si O2) are a key component that formed peat soil with smaller crystal size. Comparatively, as shown in Figure $8 \mathrm{X}$-ray powder diffraction (XRD) analysis for peat soil mixed with $\mathrm{EPP}$, quartz a, a-Si O2 incorporation observed affect the phase purity that produces contemporary mineralization element namely Muscovite-2M1, $\mathrm{V}+5$-bearing $(\mathrm{K}(\mathrm{Al}, \mathrm{V}) 2(\mathrm{Si}, \mathrm{Al}) 4 \mathrm{O} 10)$ and Zalesiite (Ca Cu6 (As O4) 2 (As O3) which is seen as a significant effect of the crystallization process that mechanically develop resistant in settlement and contributed to the stabilization development.

Furthermore, in Figure 9 X-ray powder diffraction (XRD) analysis for peat soil mixed with EPP and cement, it shows relatively the grafted EPP and cement as stabilizer materials indicates crystallinity or sharp peak due to Calcium.

The grafted EPP and cement as stabilizer materials indicates crystallinity or sharp peak due to Calcium Rhodium Deuteride (Ca8 Rh5 D23) and Triphenylchlorosilane $(\mathrm{C} 18 \mathrm{H} 15 \mathrm{Cl} \mathrm{Si})$ that formed in synthesis and structure for crystallization. In general, the rate of crystallization and the degree of crystallinity are affected by the addition of fillers in peat soil pores as stabilizer material or called EPP.

However, no significant change in the Calcium Rhodium Deuteride (Ca8 Rh5 D23) and Triphenylchlorosilane (C18 H15 Cl Si) crystalline structure was observed in the presence of EPP and cement in peat soil as shown in Figure 10. The set of reflections proves unambiguously that Eco Processed Pozzolan (EPP) contributed in peat soil stabilization.

\section{CONCLUSION}

The test in index properties are moisture content and $\mathrm{pH}$. The result of this investigation shows that the moisture content of the sample is $580.5 \%$. The findings are then thoroughly compared to previous researcher in order to ensure that the value obtained is within the range. Next, for the $\mathrm{pH}$ test, three samples were tested which are Peat Soil, EPP and Peat + EPP. This study indicate that peat recorded $\mathrm{pH}$ was 3.21, falls into acidic spectrum while EPP recorded $\mathrm{pH}$ was 13.02 and peat + EPP was 9.00, which makes both of the samples falls into alkaline spectrum. The most significant findings to emerge from this test is the $\mathrm{pH}$ for Peat + EPP which has never done before. By knowing the $\mathrm{pH}$ of the mix, it can be concluded that the mixture is in presence of soil minerals producing sodium carbonate $(\mathrm{Na} 2 \mathrm{CO} 3)$ and sodium bicarbonate $(\mathrm{NaHCO} 3)$.

As peat soil is seen as troublesome due to its uncertain behaviour, determining its index qualities is critical. Both test results were considered as acceptable when compared to previous research done by various researchers. The difference value obtained with previous past researcher are due to certain factors, for example the site condition as changes in weather and changes due to agricultural activities. Site location of samples also one of the causes for different value obtained from the findings. Different location gives different characteristics and behaviour of soil, depending on the weathering process. Peat soil is categorized as soft soils with higher settlement upon subjected to loading for a period of time. This study has found that there is only little difference in settlement between peat soil or controlled sample and peat soil mixed with EPP.

This shows that addition of moisture in the sample will increase the settlement of the sample. The evidence from this study suggests that peat soil coupled with EPP and cement as binder will significantly improve the settlement behaviour. The major finding was that the mixture of peat soil with higher concentration of EPP than cement will stabilizes the soil sample and little settlement occur over time. Thus, this study strengthens the idea that adding EPP to peat soil with help of binder or cement can enhance the properties of soft peat soil and sustain the settlement over loading for a period of time accordingly.

Recommendations are required to increase geotechnical engineering knowledge and understanding. This research uses modified Electroosmotic Triaxial Cell Technique to check the settlement rate of sample. It is clearer and more accurate when electric current is applied following the same application for Electro-Osmotic Triaxial Cell Technique for the settlement rate. The pressure applied can be varied in value to determine how the load actually affects the settlement of peat soil stabilized with EPP and cement. Peat soils also possess the behaviour of secondary compression, tertiary settlement and lateral displacement, which can be obtained by increasing the time frame of the experiment.

\section{ACKNOWLEDGMENTS}

The authors wish to express their appreciation to the Universiti Malaysia Sabah for the financial support under grant GUG0535-2/2020 with project title An Assessment of Peat Soil Settlement Behaviour Stabilized with Eco-Processed pozzolan (EPP) in Modified Electro-osmotic Triaxial Cell. The authors declare that they have no competing interests. 


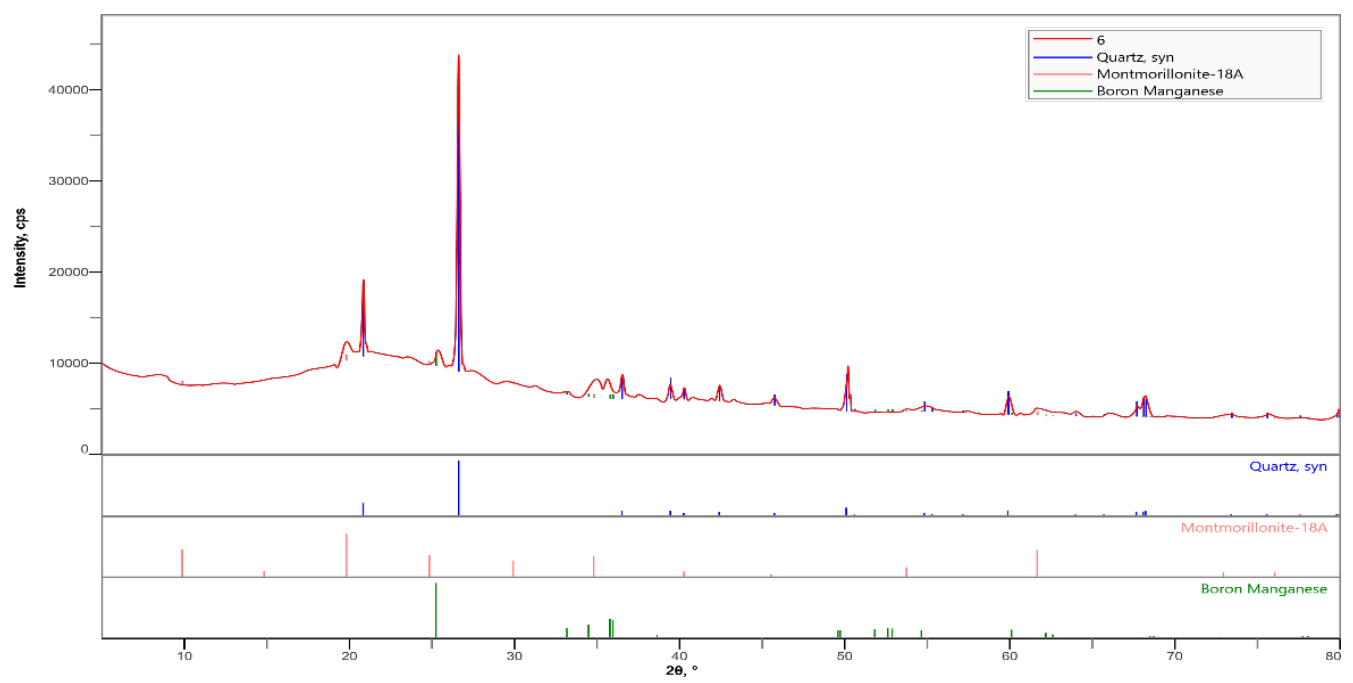

Fig. 8 X-ray powder diffraction (XRD) analysis for peat soil

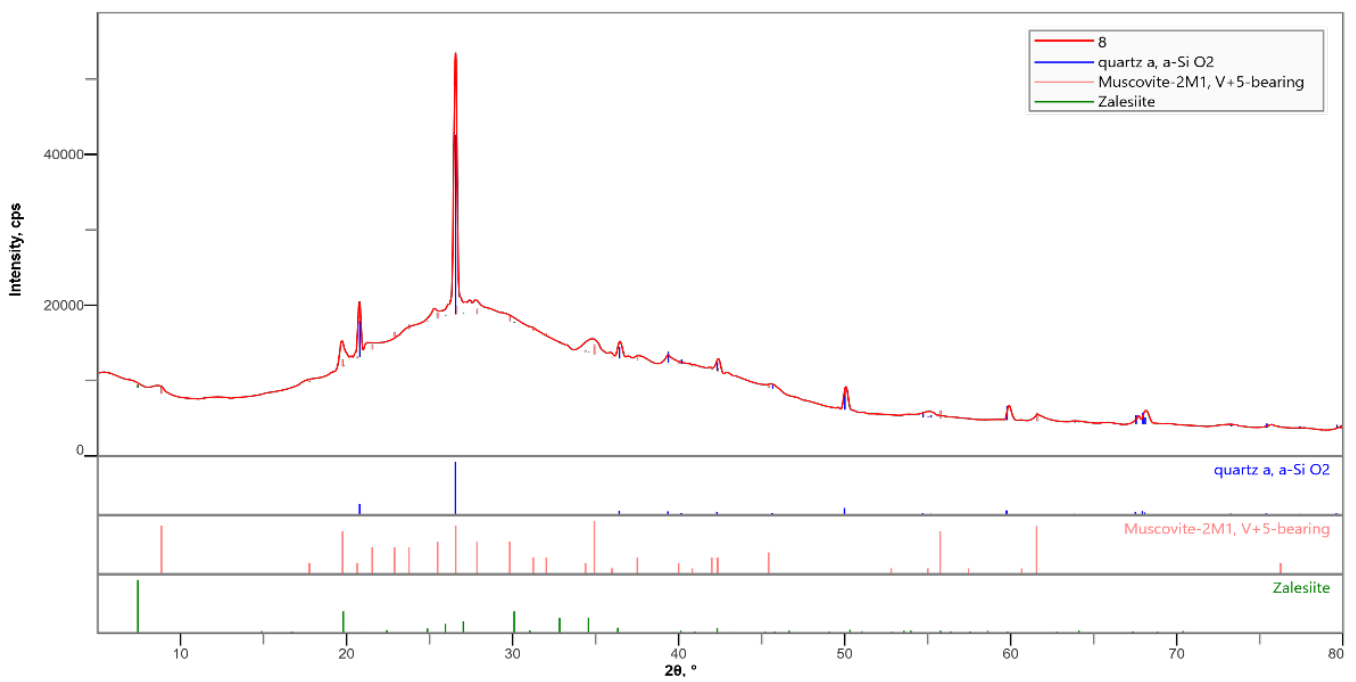

Fig.9 X-ray powder diffraction (XRD) analysis for peat soil mixed with EPP

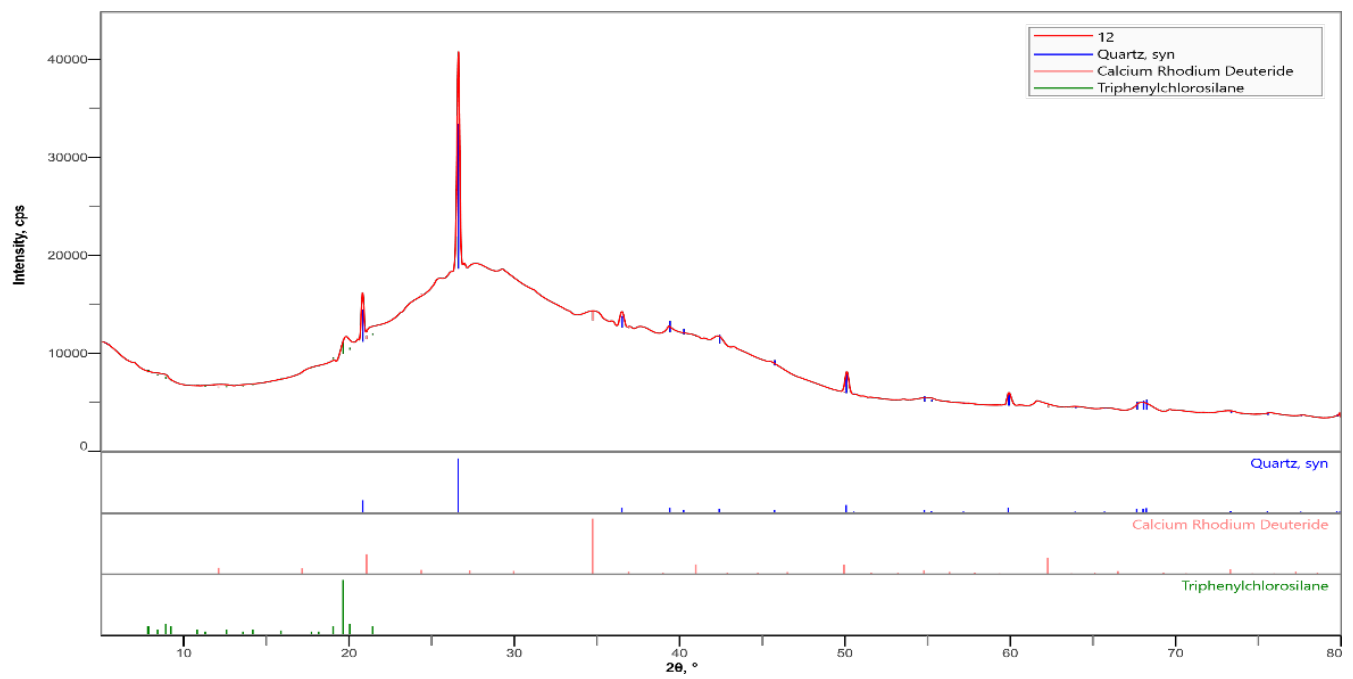

Fig.10 X-ray powder diffraction (XRD) analysis for peat soil mixed with cement and EPP 


\section{REFERENCES}

[1] Adnan, Z. and Wijeyesekera, D.C. Geotechnical Challenges with Malaysian Peat. In Proceedings of The Advances Computing and Technology 2007 Conference, 252- 261. London, United Kingdom.

[2] Wong, L. S., Hashim, R., and Ali, F. H. "Engineering Behaviour of Stabilised Peat Soil". European Journal of Science. 2008, 21.581-591.

[3] Hashim R. and Islam S. Engineering Properties of Peat Soils in Peninsular Malaysia. Journal of Applied Science. 2008, 8(22). 4215-4219.

[4] Duraisamy, Y., Huat, B. B. K., Aziz, A. Methods of utilizing tropical peat land for housing scheme. American Journal of Environmental Sciences. 2007, 3(4). 259-264

[5] El Naggar, M. H., Routledge, S. A. Effect of electro-osmotic treatment on piles Proc. ICEGround Improvement. 2004, 8 (1). 17-31.

[6] Wittle, J.K., Zanko, L.M., Doering, F., Harrison, J. Enhanced stabilization of dikes and levees using direct current technology. GeoCongress 2008: Geosustainability and Geohazard Mitigation. 2008. 686-693.

[7] Raihana F. A. R., H. Asrah and Nurfaidhi R. et al. Study of Eco-Processed Pozzolan Characterization as Partial Replacement of Cement. J. Environ. Treat. Tech. 2020, Volume 8, Issue 3, Pages: 967-970.

[8] Huat, B.B.K., Kazemian, S., Prasad, A. \& Barghchi, M. State of an art review of peat: General perspective. International Journal of the Physical Sciences. 2011, 6(8). 1988- 1996.

[9] Mesri, G., Ajlouni, M. Engineering properties of fibrous peats. Journal of Geotechnical Geoenvironmental Engineering. 2007, 133(7). 851-866.

[10] Mohamad, H.M., Zainorabidin, A., Musta, B., Amaludin, A.E., Abdurahman, M.N. Compressibility behaviour and engineering properties of north borneo peat soil. Eurasian Journal of Soil Science, 2021, 10(3), pp. 259268.

[11]Biester, H., Knorr K. H., Schellekens, J., Basler, A. Comparison of different methods to determine the degree of peat decomposition in peat bogs. Biogeosciences. 2014, 11. 26912707.

[12] Habib M. Mohamad, B. Kasbi, M. Baba, Z. Adnan, S. Hardianshah, S. Ismail, "Investigating Peat Soil Stratigraphy and Marine Clay Formation Using the Geophysical Method in Padas Valley, Northern Borneo", Applied and Environmental Soil Science, vol. 2021, Article ID 6681704, 12 pages, 2021.

[13] Benhelal, E., Zahedi, G., Shamsaei, E., and
Bahadori, A. Global strategies and potentials to curb CO2 emissions in cement industry. Journal of Cleaner Production. 2013, 51. 142161.

[14] Adnan, Z. and Mohamad H. M. A geotechnical exploration of Sabah peat soil: Engineering classifications and field surveys. Electronic Journal of Geotechnical Engineering. 2016, 21(20). 6671-6687.

[15] Ali Hauashdh, Radin Maya Saphira, R. M., Junaidah, J., Junita A. R. Stabilization of Peat Soil Using Fly Ash, Bottom Ash and Portland Cement: Soil Improvement and Coal Ash Waste Reduction Approach. Earth and Environmental Science. 2020, 498.

[16] Saedon, N. and Zainorabidin, A. An investigation of soil volume changes at four dimensional points of peat soil sample in Parit Nipah and Pontian. Applied Mechanics and Materials. 2012, 773-774. 1491-1496.

[17] Yulindasari, S., Anis, S., Wiwik, R., Hanafiah. Effect of Temperature nd heating time variation on characteristics of fibrous peat soils. IOP Conference Series Materials Science and Engineering. 2019, 620.

[18]Zainorabidin, A., Mohamad, H.M. Preliminary peat surveys in ecoregion delineation of North Borneo: Engineering perspective. Electronic Journal of Geotechnical Engineering. 2016, 21(12): 4485-4493.

[19] Paxia S. R. et al., Physical and Chemical Analysis of Land in Forest Peat Swamp in Resort Pondok soar, Tanjung Puting National Park, Central Kalimantan. IOP Conf. Series: Earth and Environmental Science 394, 2019, 012037.

[20]Zambri N. M. and Zuhayr Md. G. Peat Soil Stabilization using Lime and Cement E3S Web of Conferences 34, 01034, 2018.

[21] Khairul N. M. Y. et al. Effects of Electro Osmotic Consolidation in South West of Johor: Small Laboratory Scale. Materials Science Forum Vol. 803 (2015) pp 255-264.

[22] Mohamad, H.M., Zainorabidin, A. 2021. Young's Modulus of peat Soil Under Cyclic Loading. International Journal of GEOMATEthis link is disabled, 2021, 21(84), pp. 177-187.

[23] Mohamad, H.M., Zainorabidin, A., Zolkefle, S.N.A. Determination Of The Post-Cyclic Yield Strength And Initial Stiffness Of Two Peat Soils. International Journal of GEOMATEthis link is disabled, 2020, 18(70), pp. 172-177.

Copyright (C) Int. J. of GEOMATE All rights reserved, including making copies unless permission is obtained from the copyright proprietors. 